\title{
Botany
}

\section{Overcoming root dormancy and identifying the storage behaviour of Lilium polyphyllum seeds}

\begin{tabular}{|c|c|}
\hline Journal: & Botany \\
\hline Manuscript ID & cjb-2018-0161.R3 \\
\hline Manuscript Type: & Note \\
\hline $\begin{array}{r}\text { Date Submitted by the } \\
\text { Author: }\end{array}$ & 07-Nov-2018 \\
\hline Complete List of Authors: & $\begin{array}{l}\text { Dhyani, Anurag; High Altitude Plant Physiology Research Centre, } \\
\text { Srinagar, Post Box no. 14, Pauri Garhwal, PIN- 246174, Uttarakhand, } \\
\text { India; Jawaharlal Nehru Tropical Botanic Garden and Research Institute, } \\
\text { Karimancode P.O., Palode, Thiruvananthapuram, Pin- 695562, Kerala, } \\
\text { India } \\
\text { Baskin, Carol; University of Kentucky, Biology } \\
\text { Nautiyal, Bhagwati ; VCSG College of Horticulture, Uttarakhand } \\
\text { University of Horticulture \& Forestry, Bharsar, Pauri Garhwal, Pin- } \\
\text { 246123, Uttarakhand } \\
\text { Nautiyal, Mohan; High Altitude Plant Physiology Research Centre, } \\
\text { Srinagar, Post Box no. 14, Pauri Garhwal, PIN- 246174, Uttarakhand, } \\
\text { India }\end{array}$ \\
\hline Keyword: & $\begin{array}{l}\text { conservation, critically endangered, seed dormancy, seed storage, } \\
\text { seedling production }\end{array}$ \\
\hline $\begin{array}{r}\text { Is the invited manuscript for } \\
\text { consideration in a Special } \\
\text { Issue? : }\end{array}$ & Not applicable (regular submission) \\
\hline
\end{tabular}

\section{SCHOLARONE Manuscripts}




\section{1 (i) Full title of the paper}

2 Overcoming root dormancy and identifying the storage behaviour of Lilium polyphyllum seeds 3

\section{4 (ii) Authors}

5 Anurag Dhyani ${ }^{1,2 *}$, Carol C. Baskin ${ }^{3,4}$ Bhagwati Prasad Nautiyal $^{5}$, Mohan Chandra Nautiyal ${ }^{1}$

7 (iii) Affiliations and address (including email address)

81 High Altitude Plant Physiology Research Centre, Srinagar, Post Box no. 14, Pauri Garhwal, 9 PIN- 246174, Uttarakhand, India.

\section{(iv) Name, address, telephone, fax number and email address of Corresponding author} Name: Anurag Dhyani *Present Address: Jawaharlal Nehru Tropical Botanic Garden and Research Institute, Karimancode P.O., Palode, Thiruvananthapuram, Pin- 695562, Kerala, India

Telephone: +91-9539423674

Fax: +919(0) 4722869646

Email: anuragdhyani@gmail.com 


\section{Title of paper:}

26

27

28

Overcoming root dormancy and identifying the storage behaviour of Lilium polyphyllum seeds

\section{Abstract}

Lilium polyphyllum is a critically endangered medicinal herb of Himalaya. Seeds have epicotyl morphophysiological dormancy, and in the field a minimum of 34 weeks is required for root emergence. To date, treatments to decrease the time for root protrusion and seed storage behaviour have not been determined. We evaluated the effects of plant growth regulators and nitrogenous compounds and seed scarification on root emergence and determined the storage behaviour of seeds. Root emergence at $20^{\circ} \mathrm{C}$ was significantly increased by $100 \mathrm{ppm}$ IBA, $\mathrm{KNO}_{3}$ and thiourea and by application of $\mathrm{NaOCl}$ solution for 30 min. Mean germination time was decreased significantly by $50 \mathrm{ppm} \mathrm{GA}_{3}$ (28 days) compared to $100 \mathrm{ppm} \mathrm{GA}_{3}$ (36 days). After 12 months of dry storage, viability of seeds (TTC method) at room temperature $\left(10-35^{\circ} \mathrm{C}\right)$, $0-4{ }^{\circ} \mathrm{C}$ and $-20 \pm 1{ }^{\circ} \mathrm{C}$ was $95 \%, 100 \%$ and $100 \%$, respectively; thus, seeds have orthodox storage behaviour. Our recommendation for seedling production is to store seeds at room temperature until they can be sown under warm wet conditions. Roots emerge after about 8 weeks, and then seeds should be given a 2-week cold moist treatment to break shoot dormancy. After 2 weeks of cold, transfer seeds to warm $\left(20^{\circ} \mathrm{C}\right)$ spring temperatures to promote growth.

Keywords: conservation; critically endangered; seed dormancy; seed storage; seedling production 


\section{Introduction}

Seed germination and seedling establishment are critical stages in the life cycle of plants growing in their natural habitats (Fenner and Thompson 2005; Baskin and Baskin 2014), and have great importance for species fitness. Hence, understanding the dormancy, germination and seedling establishment are necessary for developing long term conservation strategies especially for threatened species. Information on seed germination and seedling establishment requirements is needed to artificially propagate the seedlings of endangered species for successful augmentation, introduction and reintroduction programmes (Shen et al. 2010). Target eight of Global Strategy for Plant Conservation (GSPC) aims to include at least $75 \%$ of the threatened plant species in ex situ collections, preferably in the country of origin by 2020. Ex situ seed conservation is an effective way to safeguard threatened plants from extinction (Teixido et al. 2017), and it is a practical way to preserve large amounts of genetic material in a small space with minimum risk of damage. Further, information on seed storage behaviour is needed to determine whether seeds stored in genebanks remain viable, because seed viability and germination are key factors in the success of restoration efforts, especially when stored seeds are used (Bhatt et al. 2018).

Lilium polyphyllum D. Don ex Royle, a critically endangered Himalayan species, occurs at an elevation of $2200-3200 \mathrm{~m}$ a.s.1. in Western Himalaya $\left(30^{\circ} .42 ' \mathrm{~N}, 78^{\circ} .25^{\prime} \mathrm{E}\right.$ to $30^{\circ} .99^{\prime} \mathrm{N}$, $\left.78^{\circ} .94^{\prime} \mathrm{E}\right)$, and it inhabits the understory of coniferous forests dominated by Cedrus deodara. Leaf emergence from the bulb begins in March in Garhwal Himalaya, India. Approximately two white speckled pink flowers per plant are produced, and rarely several (32 in garden, A. Dhyani, pers. obs.), and the flowering period is 15-20 days during June-July. Numerous seeds (average 
100 per capsule) are produced, during September-October. Seedlings produce increased leaf numbers by repeating the growth pattern annually, and bloom after 7-8 years in Himalayan temperate coniferous forest. A mature mother bulb develops small bulblets during the vegetative growth period (prior to flowering), and it decays after several seasons of flowering leaving a few daughter bulbs (Dhyani, unpublished).

Lilium polyphyllum bulbs contain phenolic compounds, i.e. phloridzin, caffeic acid, chlorogenic acid, 3-hydroxy cinnamic, rutin, gallic acid, ferulic acid, vanillic acid, 3-hydroxy benzoic (Giri et al. 2017). The bulbs have been used in more than 30 Ayurvedic medicinal formulations, as an aphrodisiac, astringent, antipyretic, expectorant, galactagogue, revitalizing tonic and to treat general debility (Warrier et al. 1997). Indiscriminate harvesting of bulbs, small population size, narrow geographical range, small area of occupancy, habitat degradation and continued decline in mature individuals of $L$. polyphyllum are responsible for the inclusion of the species under Critically Endangered status in IUCN Red List (Dhyani et al. 2018).

Seeds of L. polyphyllum have an underdeveloped (small) embryo and it must grow inside the seed prior to germination (morphological dormancy MD). The embryo also has physiological dormancy (PD). That is, the seeds have morphophysiological dormancy (MPD) (Dhyani et al. 2013). Seeds are dispersed in autumn (October, $\left.<15^{\circ} \mathrm{C}\right)$, and it takes about 34 weeks for the cotyledonary petiole/sheath (hereafter root) to emerge. The primary root emerges from the root-shoot axis (which is carried outside the seed via the cotyledonary petiole/sheath) after the cotyledonary petiole/sheath has emerged from the seed. Roots emerge during June $\left(19^{\circ} \mathrm{C}\right)$, and a bulblet is produced in July. The bulblet requires a cold $\left(0-4^{\circ} \mathrm{C}\right)$ moist treatment for dormancy break, and a leaf (shoot) emerges from it in mid-March to April $\left(14^{\circ} \mathrm{C}\right)$ of the 
90

91

92

following year, i.e. the second spring after seed dispersal. Thus L. polyphyllum seeds take approximately 18 months from seed dispersal to complete germination (leaf emergence) in Himalayan temperate coniferous forest of Garhwal, India (Dhyani et al. 2010). That is, seeds have epicotyl MPD (Dhyani et al. 2013).

Presently, nine different levels of morphophysiological dormancy (MPD) have been identified, based on temperature requirements for embryo growth, the breaking physiological dormancy and emergence of the root and shoot, and on the response of seeds to $\mathrm{GA}_{3}$ (Baskin and Baskin 1998; Baskin et al. 2008). One of the levels is deep simple epicotyl MPD in which considerable embryo growth occurs prior to root emergence. In deep simple epicotyl MPD warm treatment (moist at $\geq 15^{\circ} \mathrm{C}$ ) is required to break the PD of the root and cold treatment (moist at ca. 0 to $10^{\circ} \mathrm{C}$ ) is required to break PD of the epicotyl. Similar to L. polyphyllum, in seeds of Asarum canadense (Baskin and Baskin 1986), Erythronium japonicum (Kondo et al. 2002), Gagea lutea (Kondo et al. 2004), Narcissus hispanicus (Copete et al. 2011), PD of the root is broken by warm moist treatment, and PD of the epicotyl is broken by cold moist treatment.

One objective of this study on L. polyphyllum was to find a way to decrease the time required for root emergence, i.e. to either break PD or remove the mechanical resistance of the embryo covering tissues on growth of the embryo. Since treatment with plant growth regulators and nitrogenous compounds and scarification are known to overcome PD and promote germination (Bewley and Black 1994; Baskin and Baskin 2014), we hypothesized that these treatments would overcome PD of the root and thus decrease the time required for root emergence in seeds of L. polyphyllum known to have epicotyl MPD. 
A second objective was to determine the seed storage behaviour of this rare species. That

113

114

115

116

117

118

119

120

121

122

123

124

125

126

127

128

129

130

131

132

is, knowing how to maintain the viability of seeds, would facilitate storing them in a genebank.

The storage behaviour of seeds can be categorised as orthodox, recalcitrant and intermediate (Roberts 1973; Ellis et al. 1990, 1991). Orthodox seeds have low moisture content (MC) after dispersal and can be dried to $5 \%$, or lower, and stored at subzero temperatures (optimum= $18^{\circ} \mathrm{C}$ ) for long periods without loss of viability. However, freshly matured recalcitrant seeds have a high MC and lose viability rapidly if they are dried to a MC of less than $20-30 \%$. Further, they cannot be stored at temperatures below $0^{\circ} \mathrm{C}$. Seeds with intermediate storage behaviour survive a $\mathrm{MC}$ of $\sim 6-12 \%$ and can be stored at cool $\left(10-0^{\circ} \mathrm{C}\right)$ temperature; however, subzero temperatures rapidly reduce viability in these seeds. Seeds of $L$. polyphyllum live in the field in the Himalayas from dispersal time in September-October to the following June when it is warm enough for PD of the root to be broken, after which it emerges. Since seeds in the field survive exposure to low winter temperatures before root dormancy is broken, we hypothesized that they have orthodox storage behaviour.

\section{Materials and Methods}

\section{Seed harvesting and handling}

Ripe seeds of L. polyphyllum were harvested during the first week of October 2008 in Dhanaulti $\left(2200 \mathrm{~m}\right.$ a.s.1., $\left.30^{\circ} .42^{\prime} \mathrm{N}, 078^{\circ} .25^{\prime} \mathrm{E}\right)$ in (Western Himalaya) the Uttarakhand state of India. The plants were growing under the dense canopy of coniferous woodlands. We sampled 25 plants for seed collection, and each plant had approximately two capsules with 100 seeds/capsule. Mature capsules were dried for one week at ambient room temperature, after 
133 which seeds were removed manually from them and used in experiments after 5 days of drying

134 at room temperature. The criterion for seed germination in this study was emergence of the cotyledonary petiole/sheath, which we will refer to as "germination" or as "root emergence".

Effect of plant growth regulators, nitrogenous compounds and seed scarification on root emergence gibberellic acid $\left(\mathrm{GA}_{3}\right)$ and indole butyric acid (IBA), and in nitrogenous compounds potassium nitrate $\left(\mathrm{KNO}_{3}\right)$ and thiourea $\left(\mathrm{CH}_{4} \mathrm{~N}_{2} \mathrm{~S}\right)$ for $24 \mathrm{hrs}$. Previous studies revealed that seeds were water-permeable (Dhyani 2012). Seeds were scarified by soaking them in sodium hypochlorite ( $\mathrm{NaOCl}, 4 \%$ available chlorine) for 30 and 45 minutes; seeds soaked in distilled water for $24 \mathrm{hrs}$ served as the control. For each treatment, three replicates of 48 seeds were used. After all treatments, seeds were sown at a depth of approximately $1 \mathrm{~cm}$ in styrofoam trays containing a mixture of soil, sand, and litter in 1:1:1 proportion and placed in a non-temperature-controlled greenhouse (hereafter referred to as the 'greenhouse') at Srinagar Garhwal (550 m a.s.1.). The day and night temperatures in the greenhouse were about 28 and $12^{\circ} \mathrm{C}$, respectively, (average of $\left.20^{\circ} \mathrm{C}\right) ; 20^{\circ} \mathrm{C}$ had previously been shown to be a favourable temperature for root emergence (Dhyani et al. 2013). The soil was moistened, as required, with running tap water to keep the surface moist. Germination was monitored weekly for two growing seasons. Seeds were lifted manually and examined for root emergence, and germinated seeds were moved to other trays. The germination percentage was calculated by dividing the number of germinated seeds by the total number of sown seeds in each tray and mean germination time (MGT) was calculated as 
154

155

156

157

per Ellis and Roberts (1981). MGT is a measure of the rate of germination and of the sharpness of the germination peak.

\section{Effect of storage conditions on seed viability}

The moisture content (MC) of seeds was determined by the oven-drying method, i.e. $103^{\circ} \mathrm{C}$ for $17 \mathrm{hrs}$ (ISTA 2012). Fresh seed viability was tested using 2,3,5- triphenyl-2Htetrazolium chloride (TTC) prior to commencement of experiments (ISTA 2012). Three replicates of 20 seeds were incubated on moist filter paper at room temperature for $24 \mathrm{hrs}$ and then cut along the longitudinal axis with a razor blade. Both seed sections were incubated in a $0.1 \%$ aqueous solution of TTC for $24 \mathrm{hrs}$ at $37^{\circ} \mathrm{C}$ in darkness. Strongly red-stained seeds were considered to be viable.

To determine the effect of storage conditions on seed viability, seeds were placed in airtight polythene bags to maintain the original $\mathrm{MC}$ and stored at different temperatures: (i) deep freezer $\left(-20 \pm 1^{\circ} \mathrm{C}\right)$, (ii) refrigerator $\left(0-4^{\circ} \mathrm{C}\right)$, and (iii) room temperature $\left(10-35^{\circ} \mathrm{C}\right)$. At 3-month intervals for 1 year, viability of stored seeds was tested by the TTC method and seed MC was determined, as described above.

One way ANOVA with LSD (Least significant difference) at 5\% level of significance were used to analyse the effect of different plant growth regulators, nitrogenous compounds and scarification on germination and mean germination time. The Tukey-Kramer test was used to compare means of germination percentage and mean germination time between treatments when significant differences were found. All analyses were conducted in SPSS 19.0 software. 
174

175

176

177

\section{Results}

Effect of plant growth regulators, nitrogenous compounds and seed scarification on root emergence

Plant growth regulators, nitrogenous compounds and scarification with $\mathrm{NaOCl}$ had significant effects on germination $(P<0.05$, Figure 1$)$. Germination of seeds treated with $\mathrm{GA}_{3}$ and $50 \mathrm{ppm}$ IBA did not differ significantly from that of the water control. The highest germination (50.6\%) was obtained from seeds treated with $\mathrm{NaOCl}$ for $30 \mathrm{~min}$, but germination after this treatment did not differ significantly from that of seeds treated with $100 \mathrm{ppm}$ IBA, $\mathrm{KNO}_{3}$ and, thiourea or 45 min scarification with $\mathrm{NaOCl}$. However, treatment of seeds with 100 ppm IBA, $\mathrm{KNO}_{3}$, thiourea or $\mathrm{NaOCl}$ significantly increased germination compared to the water control and seeds treated with $\mathrm{GA}_{3}$. Approximately $50 \%$ of the seeds treated with $\mathrm{NaOCl}$ for 30 min did not germinate. Further, $58-75 \%$ of the seeds treated with plant growth and nitrogenous compounds and $75 \%$ of the control seeds failed to germinate (Figure 2). However, 50 ppm GA 3 significantly reduced MGT (28.7 days) compared to 100ppm GA (36.1days).

\section{Effect of storage conditions on viability}

At time of collection, $100 \%$ of the seeds were viable. Viability of seeds stored at room temperature decreased by $97 \%$ after 9 months, but it remained unchanged for seeds stored in the refrigerator and deep freeze. After 12 months storage at room temperature $\left(10-35^{\circ} \mathrm{C}\right), 0-4^{\circ} \mathrm{C}$ and $-20 \pm 1^{\circ} \mathrm{C}$, seed viability was 95,100 and $100 \%$, respectively, and $\mathrm{MC}$ was $6.8,8.8$ and $9.8 \%$, respectively (Table 1). 


\section{Discussion}

Freshly matured seeds of $L$. polyphyllum are dormant. Before the root can emerge, the small embryo grows, and PD of the root is broken. Since both the root and the shoot have PD, the embryo has low growth potential and cannot overcome the mechanical resistance of the endosperm and seed coat. Thus, scarifying seeds of L. polyphyllum with $\mathrm{NaOCl}$ (Figure 1) and either removal of the seed coat or mechanically scarifying the seed coat on the outer three margins without disturbing embryo enhanced germination 50.6, 50 and 91\%, respectively (Dhyani et al. 2014). Scarification or removal of the seed coat reduces the mechanical resistance to germination and thus allows the embryo to grow and the root to emerge. Germination of dormant seeds of Lilium martagon var. cattaniae also was enhanced by removing the seed coat (Paric et al. 2008). Further, embryo excision accelerated seed germination in 28 Lilium species and varieties (Pelkonen 2005). In L. polyphyllum seeds under natural conditions, however, PD of the root is broken during warm moist conditions in summer, after which the root emerges.

The beneficial effects of IBA and $\mathrm{KNO}_{3}$ on germination were not investigated, but we assume they played some role in increasing the growth potential of the embryo. In addition, IBA is known to promote the formation of roots (Hartmann et al. 2002). In an earlier study on in vitro germination of L. polyphyllum seeds collected from Himalayan subalpine coniferous forest, root emergence was enhanced (91\%) by treatment with $100 \mathrm{ppm}$ IBA $\left(25^{\circ} \mathrm{C}\right.$ in $16 / 8 \mathrm{~h}$ light/dark cycle) (Dhyani et al. 2014). Potassium nitrate has been used to promote germination, especially in darkness, of seeds with physiological dormancy (ISTA 2012; Hu et al. 2014). However, seeds of L. polyphyllum do not require light for germination, and the root emerges when seeds are buried in soil. 
In the present study, a 30-minute treatment with $\mathrm{NaOCl}$ induced root emergence in

$21750.6 \%$ of the seeds within 56 days after seed sowing. However, only $15 \%$ of the seeds with

218

219

220

221

222

223

224

225

226

227 emerged roots had produced a shoot (epicotyl) after two growing seasons (A. Dhyani, pers. obs.). The remaining seeds with emerged root did not produce a shoot and eventually decayed in the styrofoam trays in the greenhouse. Thus, we can conclude that scarifying seeds with $\mathrm{NaOCl}$ and incubating them in a low elevation greenhouse does not result in high percentages of seedling production, probably because the temperature in the greenhouse was not low enough (long enough) to break shoot dormancy. In contrast, in the laboratory the root emerged from

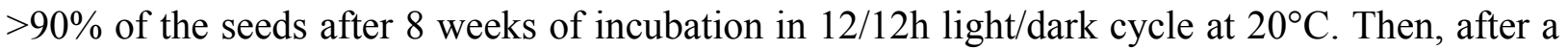
short period (14 days) of cold $\left(0-4^{\circ} \mathrm{C}\right)$ moist treatment the shoot emerged from $>80 \%$ of the seeds moved from 0-4 to $20^{\circ} \mathrm{C}$ (Dhyani et al. 2013). Thus, a high percentage of the seeds give rise to a healthy seedling in the laboratory under controlled temperature conditions, i.e. warm for root production followed by cold for shoot dormancy break. On the other hand, only a low percentage of seeds sown in a low elevation greenhouse produced a healthy seedling even when seeds have been scarified with $\mathrm{NaOCl}$ or treated with $\mathrm{GA}_{3}, \mathrm{IBA}, \mathrm{KNO}_{3}$ or thiourea. This probably is due to lack of low temperatures to break shoot dormancy.

Following the protocol of Hong and Ellis (1996), we classify the seeds of L. polyphyllum as having orthodox storage behavior. That is, seeds had high viability after being stored dry at $20^{\circ} \mathrm{C}$ for 1 year. Thus, if seeds cannot be sown immediately after collection, they can be stored dry at room temperature, $0-4^{\circ} \mathrm{C}$ or $-20 \pm 1^{\circ} \mathrm{C}$ for 1 year without loss of viability. Barton (1936) reported complete retention of viability in L. auratum seeds after 12 months in cold $\left(1\right.$ or $\left.5^{\circ} \mathrm{C}\right)$ storage. 
To produce seedlings, seeds collected in autumn can be stored dry at room temperatures

until spring. Seeds sown in April in the northern temperate region will receive enough warm moist treatment for the root to emerge in June. Treatment with $\mathrm{NaOCl}$, thiourea and potassium nitrate may decrease the time required for root emergence. However, seeds with an emerged root require at least 2 weeks of cold moist treatment (to break shoot dormancy) with shoot emergence in spring.

\section{Acknowledgements}

This work was supported by G. B. Pant Institute of Himalayan Environment and Development, Almora, Uttarakhand, India (grant number GBP/IERP/UA/04-05/12/305).

\section{References}

Barton, L.V. 1936. Germination and seedling production in Lilium sp. (Contribution from Boyce Thompson Institute)

Baskin, J.M., and Baskin, C.C. 1986. Ecophysiology of the woodland herb Asarum canadense. Am. Midl. Nat. 116(1):132-139.

Baskin, C.C., and Baskin, J.M. 1998. Ecology of seed dormancy and germination in grasses. In Population biology of grasses. Edited by G.P. Cheplick. Cambridge University Press, Cambridge, UK. pp. 30-83.

Baskin, C.C., Chien, C.T., Chen, S.Y., and Baskin, J.M. 2008. Germination of Viburnum odoratissimum seeds: a new level of morphophysiological dormancy. Seed Sci. Res. 18: $179-184$.

Baskin, C.C., and Baskin, J.M. 2014. Seeds: Ecology, biogeography, and, evolution of dormancy and germination. Academic Press, San Diego, CA. 
Bewley, J.D., and Black, M. 1994. Seeds. Physiology of development and germination. $2^{\text {ndedition. }}$ Plenum Press, New York.

Bhatt, A., Bhat, N.R., Suleiman, M.K., and Santo, A. 2018. Effects of storage, mucilage presence, photoperiod, thermoperiod and salinity on germination of Farsetia aegyptia Turra (Brassicaceae) seeds: implications for restoration and seed bank in Arabian Desert. Plant Biosyst. 1-8. DOI: 10.1080/11263504.2018.1473524

Copete, E., Herranz, J.M., Ferrandis, P., Baskin, C.C., and Baskin, J.M. 2011. Physiology, morphology and phenology of seed dormancy break and germination in the endemic Iberian species Narcissus hispanicus (Amaryllidaceae). Ann. Bot. 107: 1003-1016.

Dhyani, A. 2012. Ecophysiology, multiplication and domestication of a critically endangered medicinal herb, Lilium polyphyllum D.Don ex Royle of north western Himalaya (Ph.D. Dissertation). H.N.B. Garhwal University, Srinagar Garhwal, Uttarakhand, India.

Dhyani, A., Nautiyal, M.C., and Nautiyal, B.P. 2010. Phenology of Lilium polyphyllum: in Garhwal Himalaya, India. Acta Hortic. 855: 107-112.

Dhyani, A., Phartyal, S.S., Nautiyal, B.P., and Nautiyal, M.C. 2013. Epicotyl morphophysiological dormancy in seeds of Lilium polyphyllum (Liliaceae). J. Biosci. 38: 1-7.

Dhyani, A., Sharma, G., Nautiyal, B.P., and Nautiyal, M.C. 2014. Propagation and conservation of Lilium polyphyllum D.Don ex Royle. J. App. Res. Med. Arom. Plants, 1(4): 144147. 
Dhyani, A., Nautiyal, B.P., and Nautiyal, M.C. 2018. Distribution, status and conservation of Lilium polyphyllum (Liliaceae), a critically endangered medicinal plant from India. Plant Biosyst. 152(4): 608-611.

Ellis, R.H., and Roberts, E.H. 1981. The quantification of ageing and survival in orthodox seeds. Seed Sci. Technol. 9: 379-409.

Ellis, R.H., and Hong, T.D., Roberts, E.H. 1990. An intermediate category of seed storage behaviour? I. Coffee. J. Exp. Bot. 41: 1167-1174.

Ellis, R.H., Hong, T.D., and Roberts, E.H. 1991. An intermediate category of seed storage behaviour? II. Effect of provenance, immaturity and imbibition on desiccationtolerance in coffee. J. Exp. Bot. 42, 653-657.

Fenner, M., and Thompson, K. 2005. The Ecology of Seeds. Cambridge University Press, United Kingdom.

Giri, L., Belwal, T., Bahukhandi, A., Suyal, R., Bhatt, I.D., Rawal, R.S., and Nandi, S.K. 2017. Oxidative DNA damage protective activity and antioxidant potential of Ashtvarga species growing in the Indian Himalayan region. Ind. Crop. Prod. 102: 173-179.

Hartmann, H.T., Kester, D.E., and Davies, F.T. Jr. 2002. Plant propagation: principles and practices. Prentice Hall, Englewood Cliffs, NJ.

Hong, T.D., and Ellis, R.H. 1996. A protocol to determine seed storage behaviour. International Plant Genetic Resources Institute: Rome.

Hu, X.W., Wu, Y.P., Ding, X.Y., Zhang, R., Wang, Y.R., Baskin, J.M., and Baskin, C.C. 2014. Seed dormancy, seedling establishment and dynamics of the soil seed bank of Stipa bungeana (Poaceae) on the Loess Plateau of Northwestern China. PLoS One, 9(11): e112579. DOI: 10.1371/journal.pone.0112579 
ISTA (International Seed Testing Association). 2012. International rules for seed testing. Seed Sci. Technol. 27 (Supplement).

Kondo, T., Okubo, N., Miura, T., Honda, K., and Ishikawa, Y 2002. Ecophysiology of seed germination in Erythronium japonicum (Liliaceae) with underdeveloped embryos. Am. J. Bot. 89(11): 1779-1784.

Kondo, T., Miura, T., Okubo, N., Shimada, M., Baskin, C.C., and Baskin, J.M. 2004. Ecophysiology of deep simple epicotyl morphophysiological dormancy in seeds of Gagea lutea (Liliaceae). Seed Sci. Res. 14:371-378.

Paric, A., Hindija, J., Muratovic, E., Pojskic, N., and Bajrovic, K. 2008. Breaking dormancy of two endemic Lilium species: Lilium bosniacum (G.Beck) Beck ex Fritsch and Lilium martagon L. var. cattaniae Vis. Seed Sci. Technol. 36: 788-791.

Pelkonen, V.P. 2005. Biotechnological approaches in lily (Lilium) production. Dissertation Oulu University Press, Finland.

Roberts, E.H. 1973. Predicting the storage life of seeds. Seed Sci. Technol. 1: 499-514.

Shen, S.K., Wang, Y.H., and Ma, H.Y. 2010. Seed germination requirements and responses to desiccation and storage of Apterosperma oblate (Theaceae), an endangered tree from south-eastern China: implications for restoration. Pl. Spec. Biol. 25: 158-163.

Teixido, A.L., Toorop, P.E., Liu, U., Ribeiro, G.V.T., Fuzessy, L.F., and Guerra, T.J. 2017. Gaps in seed banking are compromising the GSPC's target 8 in a megadiverse country. Biodivers. Conserv. 26(3):703-716.

Warrier, P.K., Nambiar, V.P.K., and Ramankutty, C. 1997. Indian Medicinal Plants: A compendium of 500 medicinal plants. Arya Vaidya Sala, Oriental Longman, Chennai, India. 
1 Table1 Percent viability and moisture content of seeds of Lilium polphyllum during one year of dry storage.

\begin{tabular}{llccccc}
\hline $\begin{array}{l}\text { Temperature } \\
\left({ }^{\circ} \mathrm{C}\right)\end{array}$ & \multicolumn{5}{c}{ Storage period (months) } \\
\hline $10-35$ (Room temperature) & MC $(\%)$ & $12.8 \pm 1.8$ & $11.9 \pm 0.5$ & $10.1 \pm 1.4$ & $7.6 \pm 1.1$ & $6.8 \pm 0.8$ \\
& Viability $\%$ & $100 \pm 0.0$ & $100 \pm 0.0$ & $100 \pm 0.0$ & $97 \pm 4.2$ & $95 \pm 3.8$ \\
\hline $0-4$ & MC $(\%)$ & $12.8 \pm 1.8$ & $11.5 \pm 1.3$ & $10.7 \pm 0.8$ & $9.6 \pm 1.8$ & $8.8 \pm 1.3$ \\
& Viability \% & $100 \pm 0.0$ & $100 \pm 0.0$ & $100 \pm 0.0$ & $100 \pm 0.0$ & $100 \pm 0.0$ \\
\hline$-20 \pm 1$ & MC $(\%)$ & $12.8 \pm 1.8$ & $12.0 \pm 2.4$ & $11.3 \pm 1.4$ & $10.6 \pm 0.6$ & $9.8 \pm 1.5$ \\
& Viability \% & $100 \pm 0.0$ & $100 \pm 0.0$ & $100 \pm 0.0$ & $100 \pm 0.0$ & $100 \pm 0.0$ \\
\hline
\end{tabular}


1

2 Figure 1.Effect of plant growth regulators, nitrogenous compounds and scarification on germination (root

3

4

5

6

7 polyphyllum. Different letters indicate significant differences $(P<0.05)$ among all the treatments $(n=3)$.

8 
10

11

12

13

14

15

16

17

18

19

20

21

22

23

24

25

26

27

28

29

30

31

32

33

34

35

36

37

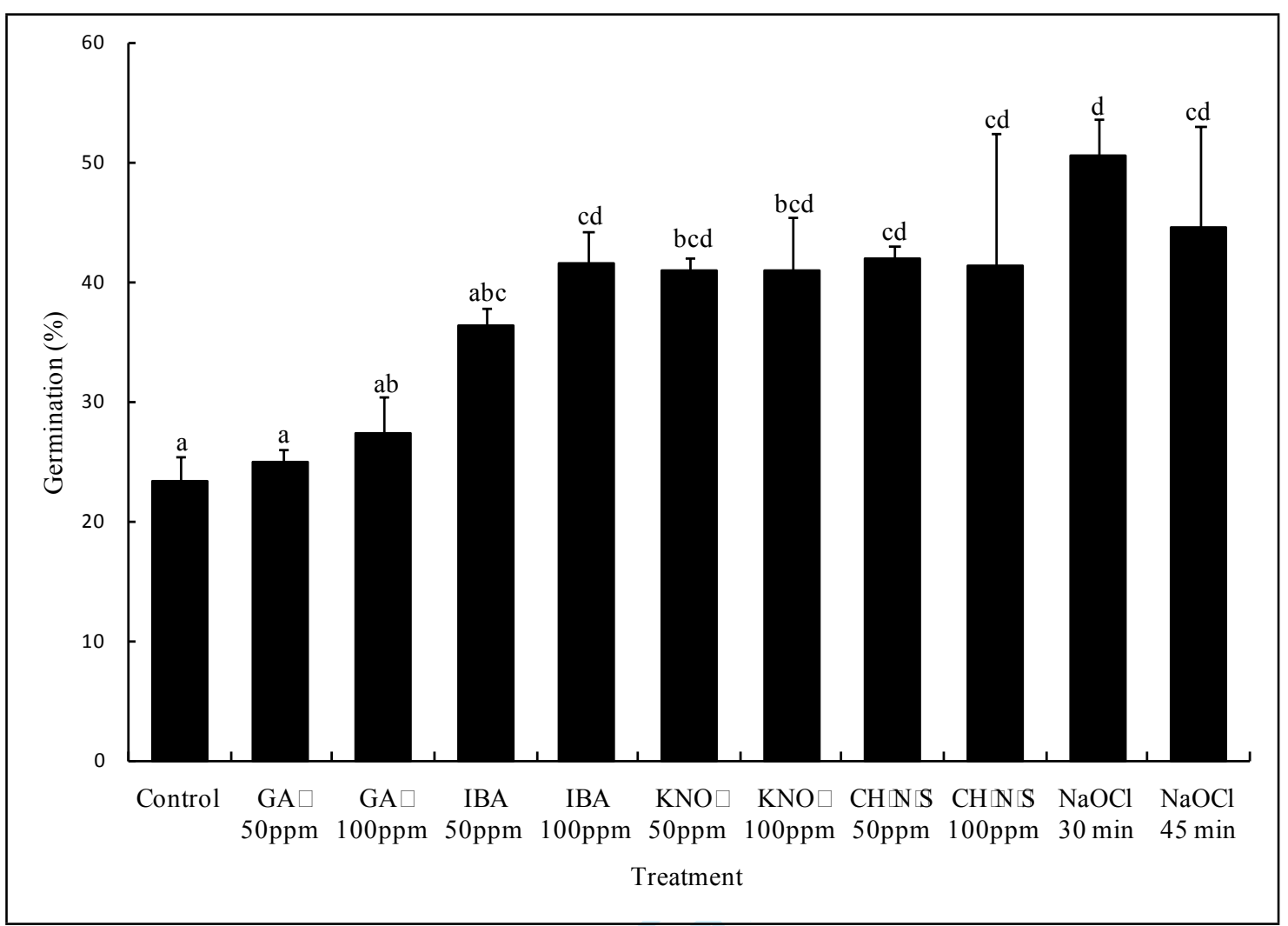

Figure 1. 
39

40

41

42

43

44

45

46

47

48

49

50

51

52

53

54

55

56

57

58

59

60

61

62

63

64

65

66

67

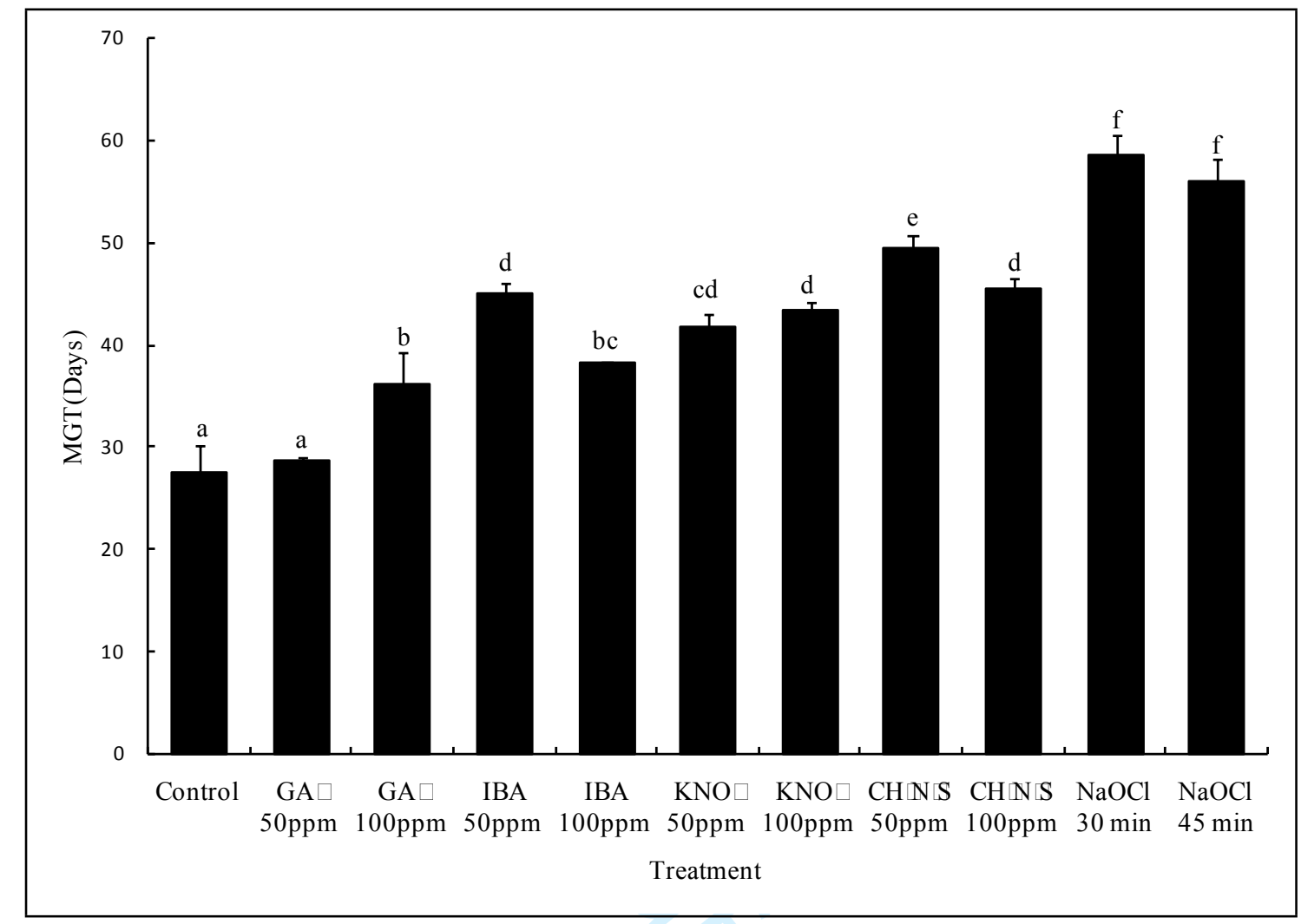

Figure 2. 